\title{
The Effects of Brain-Based Learning and Project-Based Learning Strategies on Student Group Mathematics Learning Outcomes Student Visual Learning Styles
}

\author{
La Ode Ahmad Jazuli 1*, Etin Solihatin ${ }^{2}$, Zulfiati Syahrial ${ }^{2}$ \\ ${ }^{1}$ Halu Oleo University, INDONESIA \\ 2 State University of Jakarta, INDONESIA
}

*Corresponding Author: ahmadjazuli_laode@lecturer.uho.ac.id; jazulimedsos@gmail.com

Citation: Jazuli, L. O. A., Solihatin, E. and Syahrial, Z. (2019). The Effects of Brain-Based Learning and Project-Based Learning Strategies on Student Group Mathematics Learning Outcomes Student Visual Learning Styles. Pedagogical Research, 4(4), em0047. https://doi.org/10.29333/pr/5949

Published: October 2, 2019

\begin{abstract}
The purpose of this study was to study the effect of Brain-Based Learning and Project Based Learning strategies on the results of mathematics learning in students of visual learning styles in the Basic Mathematics Introduction course at the Teaching and Education Faculty at Halu Oleo University, Republic of Indonesia. This study uses an experimental research method designed with a post-test design. Student learning outcomes data were collected through tests and learning style data collected through questionnaires. Data were analyzed by ANOVA with Dunnet's further test. The results showed that the learning outcomes of students from the visual learning style group were taught the strategy of Brain-Based Learning higher than Project-Based Learning. The conclusion of the study shows that the student learning outcomes of the visual learning style group taught by the Brain-Based Learning strategy are higher than the Project Based Learning; Student groups with visual learning style preferences are more suitable to be applied with the Brain-Based Learning strategy.
\end{abstract}

Keywords: learning outcomes, brain-based learning, project-based learning, visual learning styles

\section{INTRODUCTION}

Undergoing rigid Mathematics learning routines by completing practice questions and assignments makes this lesson unattractive and not challenging (Salinas et al., 2015). Mathematical learning methods which are dominated by exercises in solving repeated mathematical problems and algorithmic reasoning have been challenged (Bergqvist and Lithner, 2012; Bergqvist et al., 2008; Boesen et al., 2014; Hiebert, 2006). Besides that mathematics has abstract research that interprets mathematical objects as mental objects such as Plato's comments (Snyder, 2017). Learning by growing the emotional desires of students to learn so that they are not stressful, relaxed and pleasant can be a choice of learning strategies. Pedagogical interventions are structured intensively to create an active role for students in the classroom to be the instructor's choice in achieving the goal of improving learning outcomes (Berlinski and Busso, 2017). Learning outcomes which are the main capital in answering the challenges of industrial revolution 4.0 are data literacy, technology, and human capabilities. Meeting the profile of graduates 'abilities, especially higher education, is a necessity to implement the learning that optimizes students' brain functions so that they can adapt to the advancement of science and technology and the value of sustainable national civilization. The brain develops five main learning systems namely emotional, social, cognitive, physical and reflective (Given, 2007). 
The important role of various disciplines to develop students' thinking is that it is time to be integrated implemented to support the advancement of education that is compatible with the industrial revolution of the era of 4.0. Improving educational practices from different learning styles as a strategy to improve student mathematics learning achievement (Wirebring et al., 2015). Different math practice assignments can provide long-lasting behavioral and neurological differences (Ma and Ma, 2014).

Various breakthroughs in university learning strategies that can spur high-level thinking skills have emerged learning strategies based on neuroscience, biology, psychology, the relationship between learning and the brain that directs us to the role of emotions, patterns, meanings, environment, rhythm, attitudes, stress, trauma, judgment, music, movement, gender, and enrichment. Integrating learning concepts with brain works applying brain-based learning strategies or commonly known as Brain Base Learning (BBL). BBL has more positive effects on academic, achievement, attitudes, motivation and knowledge of students than teacher-centered learning (Uzezi and Jonah, 2017). Evidence The influence of the BBL strategy on academic achievement and creativity suggests testing in other subjects and grade level students and can be done for students from the University of Arts and Natural Sciences and other Professional Institutions (Ramakrishnan, 2015). However, there was no significant difference in the level of achievement of students with different learning styles based on the Experiential Learning questionnaire Kolb Style: convergence, divers, confounders, and accommodation (Duman, 2010). Other findings that apply contextual GDL-BBL-contextual reporting are used in mathematics learning for students' best mathematical achievements, but none of them are better at the same time recommending to other researchers to pay attention to differences in personality, interests, and abilities (Guang- Hong, Jian, \& Jun, 2017). A review of the brain-based learning literature reveals that one's memory and learning are strongly influenced by brain development and brain health (Arzy-Mitchell, 2013).

Renewing classroom learning practices since introducing A Nation at Risk in 1983, many efforts have been made to meet more innovative needs and learning to prepare students to meet the changing needs of the $21 \mathrm{st}$ century. Project-based learning (PjBL) is one of them because it makes students directly involved in projects that can be applied to the course or in other real-world research. PjBL has been reported to have proven effective in education at all levels of school and has been approved in various disciplines, including project management, psychology, physics, computer science, mathematics, entrepreneurship, aerospace, computers, electricity, and mechanical engineering (Straub et al., 2017). In addition, Nurma Izzati's research (2014) states that this learning has a significant significance in the ability to think creatively. Similarly, student participation in $\mathrm{PjBL}$ has a positive influence on academic achievement in grades 7 and 8 and mathematics based on the results of the Texas State Academic Academic Readiness Assessment (STAAR) and reading achievement scores (Cervantes, 2013). In contrast to the study above, the study of the learning outcomes of students who take the BBL and PjBL strategies here will be applied to students of Visual learning styles. This support was developed by Bandler \& Grinder, and Messick (Adi W Gunawan, 2004). Learning styles that have complex differences in curriculum, administration, and processes that are difficult, time and difficult to make problems (Nasution, 2008).

The purpose of this study was to examine the effect of BBL and PjBL learning strategies on learning outcomes of Basic Mathematics courses in a group of visual learning style students in the mathematics education department of the Teacher Training and Education Faculty of Halu Oleo University, Kendari city.

Students prefer the visual learning style and stimulation to create good learning outcomes for the task of remembering, understanding, remembering and connecting facts and concepts (Gilakjani, 2012; Hamdani, 2015). Visual learning styles will be effective if information can be seen as graphics, flowcharts, symbolic arrows, circles, hierarchies, and other devices. Everyone knows about the class we have. He believes in a visual representation that enhances human cognition with scaffolding information processes and visual punishment strategies that allow all students to understand how to work with fractions (Andrade, 2016). Students who increase their knowledge of spatial or visual information can be improved through learning, as well as improving mathematical results and overall academic performance (An and Carr, 2017).

Careful learning with a Brain-based teaching strategy encourages the exploration of teachers and students to solve successful problems while challenging each new challenge (Ramakrishnan, 2015); Mathematical punishments built on higher-brain long-term plans and sharpening the right cortex of superior superiors are essential for complex mathematical enhancement (Karlsson et al., 2015); Applying brain-based learning can improve student achievement and motivate mathematics learning (Ningsih, 2017).

Project-based learning increases student motivation in mathematics classes (Remijan et al., 2017); the level of academic procrastination in mathematics learning for students who get different learning strategies from conventional learning strategies (Asri, Setyosari, Hitipeuw, \& Chusniyah, 2017); Adaptive criminality is significantly better than teachers teaching with problem-based curricula and developing a better foundation of self-efficacy than traditional curriculum (Journal and Education, 2008). Wrigley agreed that project-based learning is seen as a promising strategy more than what we know about the way adults learn (Wrigley, 1998). 
Basic Mathematics Subjects for first semester students are a prerequisite in the mathematics education department curriculum so that learning such as Brain-Based Learning and Project Based Learning strategies are needed for materials that are interrelated with previous experiences (Jazuli et al., 2017). Applying various types of learning strategies is proven to be favored by students because it is reported that two-thirds of students like peer learning strategies, and others like to learn some strategies from their teacher and consider students' preferences in motivated mathematics lessons to be discussed (Wilkie, 2016).

\section{CONTEXT AND LITERATURE REVIEW}

\section{Concept of Learning Outcomes}

Learning outcomes (behavioral goals) are statements about the abilities or concepts students have acquired at the end of the learning period (Reigeluth and Beatty, 2017; Smith, 2018). The form of Gagne learning outcomes, representation of learning outcomes must fulfill five learning abilities, namely: (1) intellectual skills; (2) verbal information; (3) cognitive strategies; (4) motor skills; and (5) attitude (Gagne et al., 2005). Meanwhile, Bloom categorizes learning outcomes into three domains: cognitive, psychomotor, and affective domain (Bloom et.el., 1979).

Learning outcomes are the level or level of change of individuals who can understand in the fields of knowledge, skills, and attitudes according to the level that must be achieved at the end of the learning process (Boyd, 2004). According to Gronlund, there are two learning objectives, namely goals that support measurable change, and cognitive goals that support students' thinking abilities and difficulties (Woolfolk, 2007). While Sudjana stated that the learning outcomes were approved through tests, namely descriptive tests and objective tests (Sudjana, 2009). Description test is an option because students show their knowledge and algorithm organization as an embodiment of mental activities in addition to consideration of facilitation aspects (Hudoyo and Herman, 1988).

\section{The Concept of Brain-Based Learning Strategy (BBL)}

Neuroscience research has been carried out in the field of medicine, but the findings of researchers from educators lately are increasingly felt to have an impact on learning, motivation, and development (Schunk, 1996). The learning perspective of neuroscience is a change in cell reception carried by a neural connection that is formed, strengthened and linked to other people through the use of this connection (Jensen, 2005). Learning neuroscience is the science of the relationship of the nervous system to learning and behavior. Brain-Based Learning (BBL) is learning that is in harmony with the way the brain works naturally designed for learning (Eric Jensen, 2005). Brainbased teaching is emotional learning, social learning, cognitive learning, physical learning, and reflective learning (Given, 2007). BBL is an engagement strategy based on principles derived from understanding the brain (Eric Jensen, 2005). Meanwhile, according to Spears and Wilson, brain-based learning is a comprehensive approach to teaching based on how current research in neuroscience suggests our brain to learn naturally. Brain-based teaching optimizes the way the brain facilitates students by maximizing the theater of students' brains consisting of emotional, social, cognitive, physical and reflection learning (Sesmiarni, 2016). The BBL application needs to pay attention: Atmosphere, Brain Fitness, Choice, Difference, Emotion, Fun, Purpose, High Hope, Interest, Just Like Home, Kinesthetic, Lighting, Music, Nutrition, Online Learning, Patterns, Questions and Answers, Gifts, Seating, Technology, Water, and Sleep (Kommer et al, 2008). The Brain-Based Learning Strategy is a student-centered strategy and facilitated by teachers who utilize the cognitive abilities of students is important for teachers to empower students' cognitive abilities to make learning more meaningful (Batlolona et al., 2018; Uzezi and Jonah, 2017). Lecturers are expected to choose learning that can improve brain chemistry, improve mood and perseverance so as to improve learning outcomes (Jensen, 2009)

Brain-based learning (BBL), also referred to as educational neuroscience which examines learning as a biological process by requiring a mixture of understanding neuroscience and educational practices to enhance the brain's natural ability to learn by applying three core elements namely immersion arranged in complex environments, alertness relax, and active processing (Rodgers, 2015). The stages of BBL learning planning are Stage 1: Preexposure: giving the brain a review of new learning before it is truly explored; Stage 2. Preparation: Lecturers create curiosity and pleasure, and prepare students, Stage 3. Initiation and Acquisition, the stage of understanding creation or when the neurons "communicate" with each other. Stage 4. Elaboration: is the processing stage, demands thinking, gives the brain the opportunity to sort, investigate, analyze, test, and deepen learning. ; Stage 5. Incubation and Inserting Memory: This stage emphasizes the importance of time without activity (downtime) or rest, Stage 6. Verification and Trust Checking: this stage the lecturer checks and students realize the understanding of the material learned or not. ; Stage 7. Celebration and Integration: This stage instills all the important meanings of love for learning (Jensen, 2009). 


\section{The Concept of Project-Based Learning Strategy (PjBL)}

Project Based Learning (PjBL) is an instructional strategy that can enable you and your students to go beyond content coverage and develop the deep understandings and success skills needed to thrive in today's complex world (Larmer, 2015) . The PjBL strategy is developed based on the notion of constructivism philosophy in learning. Constructivism develops an atmosphere of learning that requires students to develop their own knowledge. A more comprehensive definition of project-based learning according to the George Lucas Educational Foundation is as follow : a) Project-based learning is curriculum fuelled and standards-based; b) Project-based learning asks a question or poses a problem that each student can answer; c) PjBL requires the teacher and/or student to develop a guiding question (a guiding question); d) Project-based learning asks students to explore issues and topics addressing real-world problems while integrating subjects across the curriculum; e) Project-based learning is a method that fosters abstracts, intellectual tasks to explore complex issues (Curtis, 2002).

Global School Net reports the results of the Auto Desk Foundation research on PjBL characteristics as follows: (a) students make decisions about a framework; (b) any problems or challenges raised to students; (c) students design the process to determine the solution to the problem or challenge proposed; (d) students are collaboratively responsible for accessing and managing information to solve problems; (e) the evaluation process is carried out continuously; (f) students regularly reflect on activities that have been carried out; (g) the final product of learning activities will be evaluated qualitatively; (h) the learning situation is very tolerant of errors and changes (Graaff and Kolmos, 2003).

According to Made Wena the Project Based Learning strategy has the following principles: 1) The principle of centralization (centrality) confirms that project work is the essence of the curriculum; 2) The driving question principle; 3) The principle of constructive investigation is a process that leads to the achievement of objectives, which contain inquiry activities, concept development, and resolution; 4) The principle of autonomy (autonomy) in project-based learning can be interpreted as the independence of students in carrying out the learning process, which is free to make their own choices, work with minimal supervision, and be responsible; 5) Realistic principles mean that the project is something real (Wena, 2009).

Project Based Learning (PjBL) is a learning strategy that starts with guide questions. The criteria for "guide questions" are confirmed as simple guiding questions to understand what is being sought (Turgut, 2008).

The steps of learning in Project-Based Learning as developed by The George Lucas Educational Foundation consist of: (1) Start With the Essential Question; Learning begins with essential questions. (2) Design a Plan for the Project; Planning is carried out collaboratively by lecturers between teachers and students are expected to feel "ownership" of the project. (3) Create a Schedule; Lecturers and students arrange a schedule of activities in completing the project, (4) Students and the Progress of the Project; Lecturers are responsible for monitoring the activities of students completing the project. (5) Assess the Outcome; Assessment is done to evaluate progress, provide feedback, (6) Evaluate the Experience; At the end of the learning process, the teacher and students reflect on the activities and results of the project that has been carried out (Curtis, 2002).

\section{The Concept of Learning Style}

The learning styles of each prospective teacher are seen as a variation in differences in individual characteristics (Katranci and Bozkuş, 2014). Individual differences in self-concept can be the internal motivation of students (McDonough and Ramirez, 2018). It is known that the dominant mental preferences from the inventory of Kolb's learning styles state that pre-service teachers prefer to learn abstract conceptualizations and more active experiments in processing knowledge (Özgen et al., 2011).

A learning style can be defined as the preference that an individual may have for processing information in a particular way when carrying out a learning activity (Valley, 2016). Learning styles as a combination of cognitive, affective and psychological factors for how individuals interact and respond to the learning environment (Duff and Duffy, 2002). Learning style is a way done by someone in carrying out activities of thinking, processing and understanding information

Student learning styles include visual, auditory, or kinesthetic learning (VAK) styles (Muwardi, 2013). Characteristics of learning styles visually through what is seen, auditory students learn through what is heard, and kinesthetic students learn through movement and touch. Although each student has a learning style (VAK), most students tend to have one of the dominant learning styles (Muwardi, 2013). In university life, students share a lot with their friends not only in school but also in their private life with students from different cultures of different regions is one of the biggest difficulties of university life in the first stage (Eskici and Saatçioğlu Tinkir, 2019). 


\section{METHOD}

This type of research is a quasi-experiment conducted at the mathematics education department of the University of Halu Oleo (UHO) of the Republic of Indonesia. The study design used post-test only with $2 x 2$ factorial design. 204 student participants were divided into three classes. The sample of groups of students from visual learning styles treated with Brain-Based Learning (BBL) and Project-Based Learning (PjBL) strategies was obtained randomly. This study uses instruments that are declared valid and reliable, namely as many as 27 learning style questionnaire items and 9 learning outcomes test items based on the results of expert validation tests and empirical validity tests. The research data analysis uses two descriptive analysis techniques in the form of average values, standard deviations are presented in the form of tables and inferential analysis techniques use ANOVA at a significant level $\alpha=0.05$ after fulfilling the requirements of analytical analysis to test the research hypothesis. about the influence of the Brain-Based Learning Strategy (BBL) and Project Based Learning (PjBL) on mathematics learning outcomes in groups of students with visual learning styles.

\section{FINDINGS AND DISCUSSION}

The results of the descriptive analysis in the form of the mean value of learning outcomes $(Y)$ groups of visual learning style students who were treated with Brain-Based Learning (A1B1) learning strategies of 89.53 and standard deviation of 3.29. While the value of Mean learning outcomes (Y) groups of visual learning style students who were treated with Project-Based Learning (A2B1) learning strategies amounted to 85.80 and standard deviation of 4.93. In full, it is presented in Table 1.

Table 1. Descriptive statistics on student learning outcomes

\begin{tabular}{cccccc}
\hline & $\mathbf{A}_{\mathbf{1}}$ & $\mathbf{A}_{\mathbf{2}}$ & $\mathbf{B}_{\mathbf{1}}$ & $\mathbf{A}_{\mathbf{1}} \mathbf{B}_{\mathbf{1}}$ & $\mathbf{A}_{\mathbf{2}} \mathbf{B}_{\mathbf{2}}$ \\
\hline $\mathbf{N}$ & 30 & 30 & 30 & 15 & 15 \\
\hline Mean & 87.00 & 86.53 & 87.67 & 89.53 & 85.80 \\
\hline ST. Dev & 4.57 & 4.95 & 4.53 & 3.29 & 4.93 \\
\hline Min & 79 & 78 & 78 & 85 & 78 \\
\hline Max & 94 & 95 & 94 & 94 & 93 \\
\hline
\end{tabular}

Sumber: output SPSS

Keterangan:

$\mathrm{A}_{1}=$ Student Group with the learning treatment of the BBL strategy

$\mathrm{A}_{2}=$ Student Group with the learning treatment of the PjBL strategy

$\mathrm{B}_{1}=$ Student Group visual learning style

$A_{1} B_{1}=$ Student Group visual learning style with the learning treatment of the BBL strategy

$\mathrm{A}_{2} \mathrm{~B}_{2}=$ Student Group visual learning style with the learning treatment of the PjBL strategy

The results of the analysis of the normality test with the Kolmogorov-Smirnov test and confirmed by the Lilliefors test at $\alpha=0.05$ resulted in all cells meeting the normal distribution. The test results of homogeneity of learning outcome data between cells have the same or homogeneous variance ( $\mathrm{p}$-value $(\mathrm{sig})=0.097>0.05)$. The results of the calculation of variance analysis on the source of the learning strategy variance $\mathrm{X}$ learning effect (interaction effect) obtained a significant interaction effect of learning strategies and learning styles on student learning outcomes $(\mathrm{p}$-value $=0.04<0.05)$ as shown in Table 2.

Table 2. Summary of ANOVA tests

\begin{tabular}{lccccc}
\hline \multicolumn{5}{c}{ Tests of Between-Subjects Effects } \\
\hline Source & \multicolumn{1}{c}{ Dependent Variable: learning outcome } & & \\
& $\begin{array}{c}\text { Type III Sum of } \\
\text { Squares }\end{array}$ & df & Mean Square & F & Sig. \\
\hline Corrected Model & $238.183^{\mathrm{a}}$ & 3 & 79.394 & 4.267 & .009 \\
\hline Intercept & 450146.817 & 1 & 450146.817 & 24192.151 & .000 \\
\hline Learning strategies & 2.017 & 1 & 2.017 & .108 & .743 \\
\hline Learning style & 66.150 & 1 & 66.150 & 3.555 & .065 \\
\hline $\begin{array}{l}\text { Learning strategies * Learning } \\
\text { style }\end{array}$ & 170.017 & 1 & 170.017 & 9.137 & .004 \\
\hline Error & 1042.000 & 56 & 18.607 & & \\
\hline Total & 451427.000 & 60 & & & \\
\hline Corrected Total & 1280.183 & 59 & & & \\
\hline
\end{tabular}




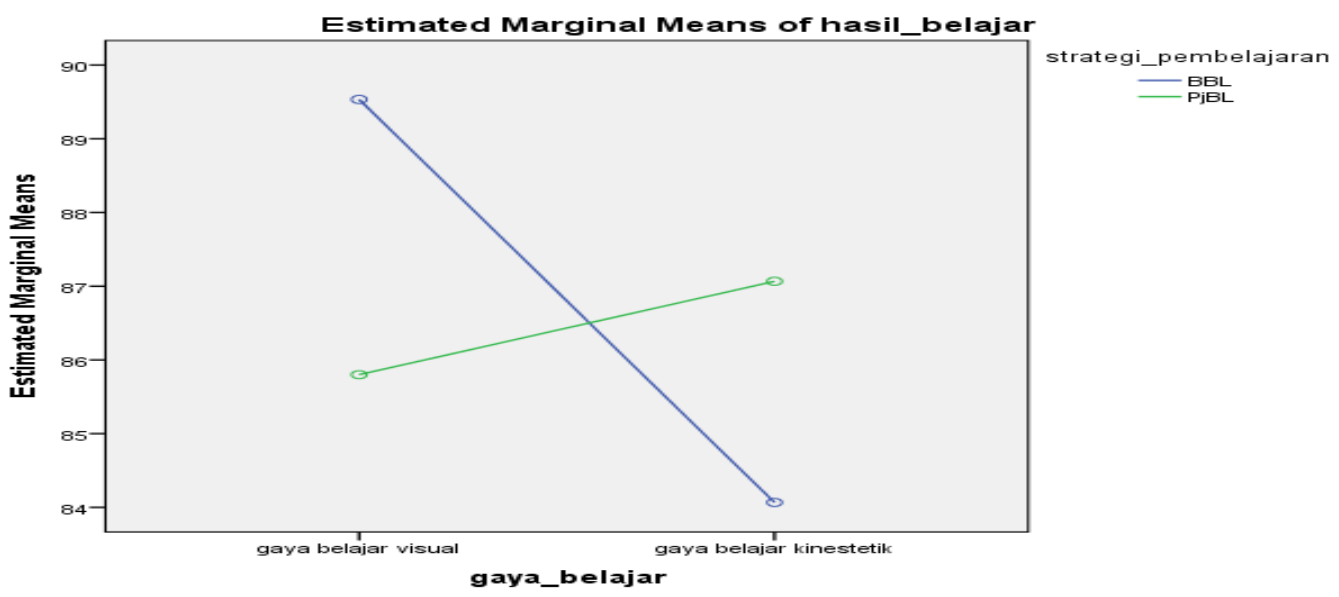

Figure 1. Interaction of variables A and B

Based on the ANOVA results, it is stated that there is an influence of variable interactions (A $x \mathrm{~B})$ such as the graph display shown in Figure 1.

The test results with Dunnet, $\mathrm{t}$ count $=2.38>\mathrm{t}$ table $=1.65$ at $\alpha=0.05$ or Ho rejected, so that student learning outcomes in the Basic Mathematics Subjects applying the BBL strategy are higher than the learning outcomes of students who apply PjBL strategy specifically for students who have a visual learning style as given in Table 3 .

Table 3. Summary of follow-up tests with the Dunnent test

\begin{tabular}{cccc}
\hline Hypothesis & $\mathbf{t}_{\text {Count }}$ & $\mathbf{t}_{\text {tab }}$ & Decision \\
\hline $\mathrm{H}_{0}: \mu \mathrm{A}_{1} \mathrm{~B}_{1}=\mu \mathrm{A}_{2} \mathrm{~B}_{1}$ & 2.370 & 1,673 & \multirow{2}{*}{$\mathrm{H}_{0}$ reject } \\
$\mathrm{H}_{1}: \mu \mathrm{A}_{1} \mathrm{~B}_{1}>\mu \mathrm{A}_{2} \mathrm{~B}_{1}$ & & & \\
\hline
\end{tabular}

This is as Brain-based learning can improve students' mathematical communication skills (Triana and Zubainur, 2019); arithmetic involves complex area networks that investigate patterns of brain activity (Peters and De Smedt, 2018); shows increased connectivity in the brains of developing students (Susac and Braeutigam, 2014). Visual learning style that relies on the sense of sight to capture learning stimuli such as observing images, map diagrams and graphs has conformity with BBL strategy learning activities that expect student achievement through creative notes in the form of mind maps visualized because visualization is very relevant for mathematics learning, which requires thinking general and abstract (Presmeg, 1986). Students make mind maps with symbolic flow diagrams and arrows between sub-concept material with colors as a concentration of Brain-Based Learning (BBL) strategies to support students' visual preferences and are motivated to represent the understanding of the material in class presentations. In line with this finding stated by Duman; Akyurek and Afacanp, BBL according to the work of the brain, contribute positively to the improvement of students' motivation, attitudes, and academic achievements (Akyürek, 2013; Duman, 2010). In accordance with the characteristics of students with visual learning styles, that is, they will be effective if the information processed looks like graphics, flowcharts, symbolic arrows, circles, hierarchies, and other devices. There was a statistically significant increase in spatial visualization skills among the experimental group and there were no gender differences in spatial visualization skills at both the pretest and posttest levels (Adaboha et al., 2017). In contrast to students who are treated with the PjBL strategy starting with the essential question step to reflection evaluation there are lecturers' oral instructions that need to be heard, develop problem solving skills, critical thinking, creativity and initiative as well as their responsibility for their own learning (independent learning) (Stoica, 2015); develop cognitive skills and improve their learning outcomes (Efstratia, 2014).

The findings of this study support the Brain-Based Learning strategy can improve student learning outcomes and increase motivation and attitudes (Akyürek, 2013; Saleh and Subramaniam, 2018); Brain-Based Learning Strategy students make mind maps make their compatibility with visual representation connect between concepts as a fundamental ability to build mathematical conceptual thinking (Rahmawati and Hidayanto, 2017); learning to use the BBL strategy has a good impact on learning achievement (Ningsih, 2017). Applying the concept of BBL learning strategies, lecturers connect learning experiences and emotional experiences based on principles derived from understanding the brain. This is because BBL reveals organized learning with the environment which has a positive effect on high-level learning, learning retention and attitudes towards student study programs (Tüfekçi and Demirel, 2009). However, experimental studies using the PjBL strategy have a positive impact on learning achievement. in line with that in a paper entitled "Using Project Mathematics in Teaching and Learning" says that 
the PBL Strategy has an important influence on student performance (Stoica, 2015); Project-based learning environments with problem-solving are far better solved in projects that develop a better environment for the development of metacognition (Sart, 2014). The literature study of the BBL and PjBL strategy concepts described above shows that each has the advantage of improving the quality of learning outcomes in groups of students with appropriate individual characteristics because both are based on constructivism where students construct concepts with mind map approaches for Brain-Based learning strategies Learning (BBL) and product-based approach to Project Based Learning (PjBL) learning strategies.

\section{CONCLUSION}

The learning outcomes of a group of visual learning style students who were treated by learning with the BrainBased Learning (BBL) strategy were higher than the Project-Based Learning (PjBL) strategy on the introductory mathematics basic course at Halu-Oleo University.

\section{REFERENCES}

Adaboha, S., Akpalua, R., Owusu-Darkoa, I. and Boateng, S. S. (2017). Using Courseware Instruction to Improve Junior High School Students' Spatial Visualization Skills. International Electronic Journal of Mathematics Education, 12(3), 353-365. Retrieved from https://www.iejme.com/download/using-courseware-instruction-to-improvejunior-high-school-students-spatial-visualization-skills.pdf

Akyürek, E. (2013). Effects of Brain-Based Learning Approach on Students' Motivation and Attitudes Levels in Science Class. Mevlana International Journal of Education (MIJE), 3(1), $104-119$. https://doi.org/10.13054/mije.13.08.3.1

Arzy-Mitchell, B. K. (2013). Brain-Based Learning for Adolescent Science Students A Review of the Literature. Doctoral Projects, Masters Plan B, and Related Works. Paper 12. http://repository.uwyo.edu/plan_b/12

Batlolona, F. A., Batlolona, J. R., Wairisal, P. L. and Leasa, M. (2018). Can the MM learning model improve results of students' mathematical cognitive learning? Eurasia Journal of Mathematics, Science and Technology Education, 14(2), 609-616. https://doi.org/10.12973/ejmste/80625

Bergqvist, T. and Lithner, J. (2012). Mathematical reasoning in teachers' presentations. Journal of Mathematical Behavior, 31(2), 252-269. https://doi.org/10.1016/j.jmathb.2011.12.002

Bergqvist, T., Lithner, J. and Sumpter, L. (2008). Upper secondary students' task reasoning. International Journal of Mathematical Education in Science and Technology. https:/ / doi.org/10.1080/00207390701464675

Curtis, D. and George L. E. F. (2002). The Power of Projects. Educational Leadership.

Duff, A. and Duffy, T. (2002). Psychometric properties of Honey \& Mumford's Learning Styles Questionnaire (LSQ). Personality and Individual Differences. https:/ / doi.org/10.1016/S0191-8869(01)00141-6

Duman, B. (2010). The Effects of Brain-Based Learning on the Academic Achievement of Students with Different Learning Styles. Educational Sciences: Theory \& Practice, 10(4), 2077-2103.

Efstratia, D. (2014). Experiential Education through Project Based Learning. Procedia - Social and Behavioral Sciences, 152, 1256-1260. https://doi.org/10.1016/j.sbspro.2014.09.362

Eskici, M. and Saatçioğlu Tinkir, N. (2019). Exposure to Emotional Violence: Relationship between University Students according to their Demographic Characteristics. Pedagogical Research, 4(1), 1-11. https://doi.org/10.29333/pr/5731

Graaff, E. D. E. and Kolmos, A. (2003). Characteristics of Problem-Based Learning. Int J Engng Ed. https://doi.org/0949-149X/91

Jensen, E. (2009). Super Teaching. California: A SAGE Company.

Karlsson Wirebring, L., Lithner, J., Jonsson, B., Liljekvist, Y., Norqvist, M., \& Nyberg, L. (2015). Learning mathematics without a suggested solution method: Durable effects on performance and brain activity. Trends in Neuroscience and Education, 4(1-2), 6-14. https://doi.org/10.1016/j.tine.2015.03.002

Katranci, Y. and Bozkuş, F. (2014). Learning Styles of Prospective Mathematics Teachers: Kocaeli University Case. Procedia - Social and Behavioral Sciences, 116(507), 328-332. https:/ / doi.org/10.1016/j.sbspro.2014.01.216

Larmer, J., Mergendoller, J. and Boss, S. (2015). Setting the Standard for Project Based Learning Acknowledgments.

Ma, V. J. and Ma, X. (2014). A comparative analysis of the relationship between learning styles and mathematics performance. International Journal of STEM Education, 1(1), 3. https:/ / doi.org/10.1186/2196-7822-1-3

McDonough, I. M. and Ramirez, G. (2018). Individual differences in math anxiety and math self-concept promote forgetting in a directed forgetting paradigm. Learning and Individual Differences, 64(June 2017 ), 33-42. https://doi.org/10.1016/j.lindif.2018.04.007

Muwardi, A. (2013). Quantum Learning: Membiasakan Belajar Nyaman dan Menyenangkan. Bandung: Kaifa. 
Özgen, K., Tataroğlu, B. and Alkan, H. (2011). An examination of brain dominance and learning styles of preservice mathematics teachers. Procedia - Social and Behavioral Sciences, 15, 743-750. https://doi.org/10.1016/j.sbspro.2011.03.176

Peters, L. and De Smedt, B. (2018). Arithmetic in the developing brain: A review of brain imaging studies. Developmental Cognitive Neuroscience. https://doi.org/10.1016/j.dcn.2017.05.002

Presmeg, N. C. (1986). Visualisation in High School Mathematics. For the Learning of Mathematics. https://doi.org/10.2307/40247826

Rodgers, D. L. (2015). The Biological Basis of Learning: Neuroeducation through Simulation. Simulation and Gaming. https://doi.org/10.1177/1046878115590585

Stoica, A. (2015). Using Math Projects in Teaching and Learning. Procedia - Social and Behavioral Sciences, 180(November 2014), 702-708. https:/ / doi.org/10.1016/j.sbspro.2015.02.181

Susac, A. and Braeutigam, S. (2014). A case for neuroscience in mathematics education. Frontiers in Human Neuroscience. https://doi.org/10.3389/fnhum.2014.00314

Triana, M. and Zubainur, C. M. (2019). Students' Mathematical Communication Ability through the Brain-Based Learning Approach using Autograph, 4(1), 1-10. https:// doi.org/10.23917/jramathedu.v1i1.6972

Tüfekçi, S. and Demirel, M. (2009). The effect of brain based learning on achievement, retention, attitude and learning process. Procedia - Social and Behavioral Sciences. https://doi.org/10.1016/j.sbspro.2009.01.316

Turgut, H. (2008). Prospective Science Teachers' Conceptualizations about Project Based Learning. International Journal of Instruction, 1(1), 61-79.

Uzezi, J. G. and Jonah, K. J. (2017). Effectiveness of Brain-based Learning Strategy on Students' Academic Achievement, Attitude, Motivation and Knowledge Retention in Electrochemistry. Journal of Education, Society and Behavioural Science, 1-13.

Valley, K. (2016). Learning styles and courseware design. ALT-J, 5(2), $42-51$. https://doi.org/10.1080/0968776970050205

Wena, M. (2009). Strategi Pembelajaran Inovatif Kontemporer: Suatu Tinjauan Konseptual Operasional. Jakarta: Bumi Aksara.

Wilkie, K. J. (2016). Rise or Resist: Exploring Senior Secondary Students' Reactions to Challenging Mathematics Tasks Incorporating Multiple Strategies. EURASIA Journal of Mathematics, Science \& Technology Education, 12(8), 2061-2083. https://doi.org/10.12973/eurasia.2016.1260a 